\title{
Mapping Women's and Gender Studies in the Academic Field in Slovenia
}

Milica Antić GABER ${ }^{1}$

$\approx$ The aim of the present paper is to map the development of women's and gender studies (WGS) in the academic field in Slovenia. Slovenia is the first of the former Yugoslav state republics in which WGS have succeeded in entering the academic field and becoming part of institutionalised university study. In this paper we will ask the following questions: How, when and why did this happen? How was this connected to women's and feminist movements and politics regarding women's issues and demands? What were the obstacles in this process? Who were the agents and what were the factors that supported demands for the incorporation of WGS in academia? How has the field evolved in the last few decades? What were the phases of this development? Which fields were the forerunners, which were the late-comers and which are still left aside? What are the thematic scopes taught in WGS courses? In which degrees are the courses offered and what are their modules? Who teaches them?

The mapping in this paper is mainly based on primary sources of university programmes and their curricula at faculties of the University of Ljubljana, as well as on interviews with important agents in the field.

Keywords: women's studies, gender studies, institutionalisation, mapping, academia, course

1 University of Ljubljana, Faculty of Arts, Department of Sociology, Slovenia; milica.antic@ff.uni-lj.si. 


\section{Mapiranje ženskih študijev in študijev spola v akademskem polju v Sloveniji}

Milica Atnić Gaber

$\propto$ Namen prispevka je mapirati razvoj ženskih študijev in študijev spola (ŽŠŠS), v akademskem polju v Sloveniji. Slovenija je prva med nekdanjimi jugoslovanskimi republikami, zdaj državami, v katerih je ŽŠŠS uspelo vstopiti v to polje in postati del institucionaliziranih univerzitetnih študijev. $\mathrm{V}$ tem prispevku se sprašujem: kako, kdaj in zakaj se je to zgodilo? Kako je to povezano z ženskim in feminističnim gibanjem in politikami do vprašanj in zahtev žensk? Kakšne so bile ovire v tem procesu? Kdo so bile_i akterke_ji in kateri so bili dejavniki, ki so podpirali zahteve za vključevanje ŽŠŠS v akademski prostor? Kako se je to področje razvilo v zadnjih nekaj desetletjih? Katere so faze tega razvoja? Katera področja so delala prodore in katera so zamujala in katera so še vedno zunaj tega procesa? Katera tematska področja se poučujejo pri teh predmetih na ŽŠŠS? Na kateri stopinji in kakšni so moduli, ki jih ponujajo? Kdo predava?

Mapiranje v tem prispevku temelji predvsem na primarnih virih o univerzitetnih programih in njihovih učnih načrtih fakultet Univerze v Ljubljani in na intervjujih s pomembnimi akterkami na tem področju.

Ključne besede: ženske študije, študiji spola, institucionalizacija, mapiranje, akademija, predmet 


\section{Introduction}

Maca Jogan, one of the professors in Slovenia who, in the field of sociology, undertook pioneering work in WGS, recollects how male professors in the 1970 reacted to her as she started to work on women's issues in academia:

"A science existed or it did not exist, asserted my colleagues. Of course I principally agreed with this statement, but I had always in mind the question: What kind of science? When, at the end of the 1970s, I wished to make a systematic investigation of the changes in the position of women, one of my colleagues, an eminent Professor, said to me: 'You are known as a really serious woman but you are entering into this very unserious field!' Nonetheless, I entered the field, though I was often very lonely" (Jogan, 2006, p. 35).

This recollection of Prof. Jogan refers to events at a time when, in the USA as well as in some Nordic countries, women's studies had already started entering university programmes. Alice E. Ginsberg, editor of the book The Evolution of American Women's Studies: Reflections on Triumphs, Controversies and Change (2008) writes in the introductory chapter that the first entries of women's studies into American universities date from the 1960s and 1970s (Ginsberg, 2008, p. 1). In her analysis of the birth of women's studies in Nordic countries, Drude Dahlerup similarly writes that they developed as a discipline in that part of the world in the 1970s and 1980s (Dahlerup, 2015, p. 1). Both authors agree that women's studies courses emerged from the women's movement. They refer to the critique of the male dominance and gender blindness of the university as it privileged the study of white middleclass heterosexual men, and they ask how this can be changed.

Comparative research on the Impact of Women's Studies Training on Women's Employment in Europe from $2003^{2}$ shows that women's studies developed unevenly throughout the nine participating countries (Finland, France, Germany, Hungary, Italy, Netherlands, Spain Slovenia, UK), starting from 1974 in Italy to 1995 in Spain (39). It was also found that these studies were initially mostly situated in social science and humanities programmes. They were largely established as master's programmes, but it was also possible to take modules as part of other disciplines. In the majority of these countries, it was also possible to gain a $\mathrm{PhD}$ in women's studies (38). The research discusses, inter alia, the processes of institutionalisation of women's studies in the respective countries. In so doing, it traces factors that promoted the process of institutionalisation and factors that hindered it. As developed by Harriet Silius (2002), these factors

2 A report on this project, in which a Slovenian team of researchers was led by Prof. Eva D. Bahovec, is available on http://cordis.europa.eu/docs/publications/1001/100124171-6_en.pdf. 
were: a high degree of university autonomy in developing curricula, modularity, support or neutrality of the women's movement regarding institutionalisation, state support for the subject and the counter effects that slow down or obstruct the process. The authors of the research agree with Silius that the institutionalisation of women's studies went through six phases: activist (individual optional modules appear in traditional degrees); establishment (generic and thematic modules are introduced, interdisciplinary co-teaching units are established); integration (women's studies modules became part of the core compulsory provision of traditional disciplines); professionalisation (women's studies degrees are introduced and women's studies staff, including professors, are appointed); disciplinisation (department-like centres for teaching, research and documentation are established); and autonomy (women's studies function like any other discipline, with accreditation, funding and degree-awarding rights) (41). Based on the reported data, the institutionalisation phase of women's studies in the countries analysed was rated as high, low or medium. Slovenia appears in the lower part of the ranking table with a low institutionalisation rate, accompanied by Italy and France, where the women's movement was strongly against institutionalisation (42) and Hungary, where the wider political culture embodied prevailing traditional attitudes towards gender equality.

Not long ago, one of my third-year students at the Faculty of Arts who had chosen my course Sociology of Gender told me that it was the first course on gender available to her during her entire three years of study (not in the Sociology Department, but in another social science department) in her BA programme. We can therefore envisage that overall there have been no fundamental changes in this respect. This is why we would like to document and delineate the process of the institutionalisation of women's and gender studies at selected faculties of the University of Ljubljana in the last few decades (from the time when a renowned professor was faced with the remark that dealing with women's issues was not a job for a serious sociologist) and try to answer several questions. When, how and under what social circumstances did the development of women's and gender studies (WGS) occur? Were there any obstacles in this process? How was this connected to the women's and feminist movement and politics regarding women's issues and demands? Who were the agents and what were the factors that supported demands for the incorporation of WGS in academia? How has the field evolved in the last few decades? Which academic fields (disciplines) were the forerunners, which were the latecomers, and which are still left aside? What is the thematic scope being taught in WGS courses? What thematic courses are offered and in which degrees? Who teaches them? What were the phases of this development? 


\section{Methodology and sources}

The mapping of the development of WGS in the present paper is primarily based on an examination of the university programmes of faculties of the University of Ljubljana and their curricula, as well as on interviews with or reports of the important agents in the field: the informants. Structured interviews were carried out in spring 2016 and were approximately 30-40 minutes long. Some informants chose a written form of interview or preferred to submit their own written reports. ${ }^{3}$

The knowledge and courses that have been developed in other institutions in Slovenia - Institutum Stidiorum Humanitatis or the Peace Institute, as well as certain feminist NGOs such as Lezbično feministična akademija (LesbianFeminist Academy) or, in the last few years, Rdeče zore (Red Downs) and $\mathrm{Za}$ vod Transfeministična iniciativa - TransAkcija (Transfeminist Initiative Institute - TransAction), to name just a few - will be left aside in the present paper. We are aware that some of these contributions are a very important part of knowledge production and knowledge dissemination on gender and sexuality, and that they have paved the way to a better understanding of gender and gender relations in society; in this paper, however, we would like to concentrate on the narrowly understood institutionalised part of knowledge production in the field of WGS that gives officially recognised diplomas or other certificates to participants.

In this sense, we understand WGS as a discipline that is based on the assumption that gender is a defining category that influences our experience and knowledge (Bowles \& Klein, 1983; Humm, 1989). It is a critical project that examines "how science perpetuates forms of discrimination and even of exclusion, but it is also a creative field in that it opens up alternative spaces to women's selfrepresentation and intellectual self-determination" (Braidotti, 2003, p. 33). It is by definition a political project that has a transformative agenda and an inter- and trans-disciplinarily orientation, despite being predominantly based in social sciences (Silius, 2002) and included in the post-secondary education system (Griffin, 2006). If there is a difference between women's and gender studies, we can

3 The informants (eight in total) are lecturers in WGS from the Faculty of Social Sciences, the Faculty of Arts, the Faculty of Social Work, and the Faculty of Education of the University of Ljubljana. Some of them were interviewed, while others gave the author written answers or unpublished papers (speeches) or provided the curricula of the programmes of their faculties. Some of the informants requested anonymity, which is why the paper does not disclose their names. I would like to thank all of them, especially those who were active in the first decades. Without their peer help and sharing of their rich information, the present analysis would not have been possible. The author of this paper is herself one of these actors. Although this could represent an important advantage, it could also be a hindrance to the objectivity of the presented data and its analysis. For this reason, the author has decided to document the majority of the information and facts included in the paper in footnotes, so that readers can check them. 
understand women's studies as studies that "show how white western men were treated as (gender neutral) generalized human, and put the emphasis on the missing part of humanity - women - their experiences, interests and needs and especially create a new knowledge from the women's perspective" (Davis, Evans, \& Lorber, 2006, p. 2), while gender studies are studies that "put an emphasis on the relation between women and men, especially power relation, domination and oppression. Their emphasis was on organisation and structures of society as well as on cultural and knowledge production" (ibid.). ${ }^{4}$

As is evident, our theoretical starting point is connected to the Western theoretical tradition and the WGS that were developed at European and American universities. This is not to say that there was no specific knowledge regarding this issue in Central Eastern Europe; however, such knowledge was not explicit, coordinated and organised in the academic field, but scattered in various arenas of society.

In our analysis, we therefore only include courses that have the following terms in their names: "women", "man", "masculinity", "femininity", "feminism", "gay", "lesbian" or "gender". This enables us to conclude that the courses belong to the field widely recognised as Women's or Gender Studies. ${ }^{5}$

We are aware that there may be other courses that partly touch upon the issues of women or gender, and that their titles contain terms other than those mentioned above. Nonetheless, if they do not clearly display a focus on the terms mentioned above, we did not include them in the analysis, as, to the best of our knowledge, they cannot be understood as part of the gender-sensitive curricula.

In the following section, we will try to identify the phases of the development of WGS at the University of Ljubljana and determine the characteristics of their development.

\section{The times of "smuggling" women's issues into "serious" courses (the late 1980s)}

There is a great deal of truth - and it can be found in numerous reflections of the pioneering time of women studies - in a recollection of Ginsberg in an interview about the development of women's studies in the USA:

"One of the key challenges to women's studies in the early years was most certainly that it was intimately connected to the feminist movement for

4 The author of the present paper is aware that there are not only two genders, and that this awareness has entered WGS with transgender studies. The focus of this paper is, however, only on WGS.

5 The only exception to this rule is in the first decade. The reason for this is explained later in the text. 
social change. It was, in fact, referred to as the 'academic arm' of the women's movement. These first courses, and the brave women who taught them, made no bones about the fact that knowledge was political" (...) "Women's studies also distinguished itself by claiming that the personal was political, and thus making a place within courses for women to talk about their own experiences, expectations, and socialization." (Jaschik, 2009).

Let us therefore see what connections can be found between feminist attempts and women's studies in the Slovenian context. In a diagram from the book Kako smo hodile $v$ feministično gimnazijo (How We Attended a Feminist Grammar School), one can trace the formation of feminist groups in Slovenia and see the lively chain of historical events from the mid 1980s on (Jalušič, 2002, pp. 290-291). First among them is Ženska sekcija Društva sociologov Slovenije (The Women's Section of Association of Slovene Sociologists) established in 1984. It was followed by the activist group Lilit in 1985, Lezbična lilit (Lesbian Lilith) in 1987, and SOS telefon za ženske žrtve nasilja (SOS Helpline for Women Victims of Violence) in 1989, to list only a few. From the different types, content and orientations of the groups, one can conclude that there was a widespread need for gathering, discussing issues and offering mutual assistance, as well as for collective actions. A desire for gender-sensitive knowledge and understanding of women's lives can also be traced, as there were working groups that dealt with the women's movement, women's everyday lives or politics, such as Skupina Ženske za politiko (Group Women for Politics, 1990).

In the 1980s - despite the fact that we recall these times as the most beautiful times of our lives under socialism - due to a loosening of the power of the League of Communists in all spheres of life, the academic field was not so open to these new topics. There were a few feminist-oriented academics, mostly in social sciences and humanities departments, but they were mainly younger, less powerful and/or not highly positioned in the field in comparison with their male colleagues, which prevented them from initiating substantial changes with regard to introducing special courses and women's studies programmes. They were, however, smart, and, as one of our informants said, they started "smuggling" women's issues into the already established courses and disciplines.

Nevertheless, it is worth mentioning that the first course that bears the word "women" in its title was the course Žensko pismo (Women's Writings) at the Department of Slavic Languages of the Faculty of Arts, taught by the then Belgrade professor, Svetlana Slapšak in 1986. 
Only a year later, at the Faculty of Sociology, Political Sciences and Journalism, now known as the Faculty of Social Sciences, one of our informant reports ${ }^{6}$ that courses in which women's issues were taught commenced in the 1987/88 academic year.7 The titles of these courses did not refer to women's issues, which were concealed within broader topics such as "public and private" or "the family", thus providing a good example of the aforementioned smuggling strategy. Apart from this, there were also courses ${ }^{8}$ touching upon social inequalities of women and men offered as research seminars. ${ }^{9}$ These courses already bear the word "women" and even "femininity and masculinity" in their names, but they were in fact research seminars rather than "real" courses; they nonetheless attracted many students and broadened their interest in women's issues.

All but one of the lecturers at that time were female professors, and one of our informants - the lecturer who taught these subjects - recalls that, in the process of introducing these courses, the argument was that famous universities such as Oxford, Cambridge, Paris, Milan and others already had WGS courses and even entire programmes, and that it was therefore inconceivable that we would not start introducing such courses at our university. As teachers, they nevertheless met with the remarks from their male colleagues such as: "OK then, but where are the men?" or: "What do you do there - crochet?" They did, of course, disregard this response and continued doing what they had planned to do. In terms of Silius's (2002) institutionalisation phases, this phase could be considered an activist phase.

In this initial phase of the development of WGS, we see two parallel processes: on the one hand, we witness the mimicry and masking the new courses concerning women's issues with more "scientific" titles in order to hide the real

6 Almost all of the data about the courses in the decades before the new Bologna programmes at the Faculty of Social Sciences has been obtained from an unpublished paper by Maca Jogan entitled 1961-2011: Spol, spola, spolna neenakost in znanost na FDV (Spremno besedilo $k$ razstavi ob 5o-letnici FDV) (1961-2011: Gender, Two Genders, Gender Inequality and Science at the Faculty of Social Sciences (Accompanying Text for an Exhibition on the $50^{\text {th }}$ Anniversary of the Faculty of Social Sciences)). I would like to thank Prof. Jogan for her selfless assistance in the attempt to gather the important historical facts and other data for this early period of the development of WGS in Slovenia, as well as other colleagues and professors from the Faculty of Social Sciences, Tanja Rener, Alenka Švab and Zdenka Šadl, who shared their recollection of this process in the later phases of development. I would also like to thank Neli Babić and Prof. Monika Kalin Golob for further clarifications concerning recent developments.

7 Teorije zasebnost - razvoj in kriza dialektike zasebno - javno (Theories of Privacy - Development and Crisis of the Dialectics of Private-Public) and Socialna zgodovina družine (Social History of the Family) were two such research seminars, both executed by Tanja Rener.

8 These were: Žensko vprašanje v preteklosti in sodobnosti (Women's Questions in the Past and Present), M. Jogan; Lik ženske v množičnih občilih, (The Figure of Woman in the Media), M. Jogan, Z. šadl; Politična participacija žensk $v$ Sloveniji (Political Participation of Women in Slovenia), T. Rener; Ženskost in moškost (Femininity and Masculinity), S. Južnič.

9 Research seminars differ from (optional) courses in that the emphasis is on independent research undertaken by students lead by a professor, resulting in a joint research project. 
content and avoid potential opposition to their introduction to the curricula; almost simultaneously, there was the introduction of courses that openly thematise gender relations, connecting them with social and economic inequalities. Although the courses were not numerous, they were almost exclusively linked to the field of sociology. We can therefore consider sociology - and not literary or English or American studies departments as in some other East Central European countries ${ }^{10}$ - as the discipline most open to women's and gender issues in Slovenia. Although this warrants thorough consideration and recognition, it will be left to our future research. Despite the fact that all but one of the courses were offered as research seminars (which can be different each year and are not part of core academic curricula) rather than as obligatory or optional courses, and therefore remained on the margins of the academic field, they were important harbingers of change, especially due to the fact that they were all connected to the research activities of teaching staff who would, in the near future, also influence and enlarge knowledge production in this field. Needless to say, this was done by professors (all but one female) whose professional careers had been developed around one or other of the "serious" sociological questions (work, family, theoretical approaches, etc.)

\section{Expansion and upgrading of women's studies courses in the 1990 s}

In the early 1990s, activities in civil society and women's groups intensified. In addition to the aforementioned groups, new ones arose, including various self-help groups, Ženska svetovalnica (Women's Counselling), Prenner

Club, Ženske v črnem (Women in Black), etc., each dealing with specific issues. Women's sections were established in the formal politics of left-wing parties. Their activities influenced changes on the institution-building side of the newly established nation state: Parlamentarna komisija za žensko politiko (Parliamentary Commission for Women's Politics, 1991) and Urad za žensko politiko (Office for Women's Politics, 1992) were very proactive and, at that time, oriented towards opening public discussion of the new feminist agenda. It became increasingly obvious that what was missing was an organised women/feminist research and knowledge production initiative/centre/organisation. One attempt to interconnect feminist research, knowledge production and the problems that women face in everyday life was a special issue on abortion Abortus - Pravica do izbire!? (Abortion!? The Right to Choose!?, 1991), as these were the times when

10 Cf. Mlinarevic et. al. (2010) and the results of Tuning Educational Structures in Europe, Reference Points for the Design and Delivery of Degree Programs in Gender Studies, Athena. 
the new right wing wanted to annul the constitutional article that guaranteed the right of abortion on demand.

This issue was also in the air at the first international colloquium on women's studies in 1991, in which two prominent feminist scholars from the UK participated as the keynote speakers: Denise Riley and Lynne Segal. Papers from this gathering were published in a special issue of Časopis za kritiko znanosti (Journal of Critique of Science, ČKZ) in 1993. The goal of feminist knowledge production was partly fulfilled with the establishment of the first scientific feminist journal Delta (1995), whose driving force was Eva D. Bahovec.

These events show how lively the beginning of 1990 s was in terms of women's groups, and how many different initiatives emerged from small circles of feminist scholars and NGO activists. It is true that some of them were more scholarly and others more practically oriented (Jalušič, 2002), but they all wanted to initiate changes in women's lives and empowerment, as well as to be actively involved in the vast structural modification of society in that important transitional period.

Women in the academic field successfully initiated new courses at the undergraduate and postgraduate levels. In the Sociology Department of the Faculty of Social Sciences in 1993/94, one optional course ${ }^{11}$ was given and several optional seminars ${ }^{12}$ were offered to the students (Jogan, 2011).

The next important step in the development of WGS at this faculty was made when a new master's level ${ }^{13}$ programme entitled Seksizem kot (sodobna) tradicija (Sexism as (Contemporary) Tradition), coordinated by Maca Jogan, was launched in the 1992/93 academic year with several distinct courses ${ }^{14}$ aimed at theorising gender inequality (Jogan, 2011).

At the Sociology Department of the Faculty of Arts, ${ }^{15}$ several optional

11 This was: Sociologija odnosov med spoloma (Sociology of Gender Relations). The name was later changed to Sociologija spolov (Sociology of Gender), first taught by M. Jogan.

12 These were the following: Seksizem, telesnost, čustvenost (Sexism, Embodiment, Emotionality), M. Jogan, Z. Šadl); Socialna zgodovina žensk $v$ Sloveniji v prvi polovici 2o. Stoletja (A Social History of Women in the First Half of the $20^{\text {th }}$ Century), T. Rener; and Feminizem in sociologija (Feminism and Sociology), T. Rener.

13 Apart from this programme, several subjects in the two master's programmes Sociology of Everyday Life and Anthropology had a number of courses in which gender issues were included, such as: Socialna konstrukcija spolne/etnične identitete (Social Construction of Gender and Ethnic Identity), S. Mežnarič; Antropologija spola (Anthropology of Gender), S. Južnič, V. Godina, I. Šumi; Antropologija in feminizem (Anthropology and Feminism), Bošković.

14 These were: Feministična teologija (Feminist Theology), A. Grünfelder; Evropska integracija in antiseksistična politika (Feminist Integration and Antisexist Politics), A. Barbič, T. Rener; Seksizem, telesnost, čustvenost (Sexism, Embodiment, Emotionality), M. Jogan, M. Kožuh Novak, Z. Šadl; Socialno razlikovanje $v$ prostem čas (Gender Differentiation in Free Time), N. Černigoj Sadar.

15 The data about the development of WGS at the Faculty of Arts were gathered by Mirna Berberović with the assistance of Andreja Končan, Janja Sešek and Tanja Hribar, to whom the author of the present paper owes thanks. Many thanks are also due to all of the lecturers of specific courses who helped clarify the ambiguities and uncertainties related to these developments. 
courses devoted to women's or gender issues started to be taught in 1992/93. ${ }^{16}$ However, the real demarcation lane at this department was drawn in 1999, when Sociologija spola (Sociology of Gender) was introduced as a mandatory course. ${ }^{17}$ With this step, "sociology of gender" was accepted as an "equal among equals" and as a serious sub-discipline in sociology that all of the students had to be acquainted with. In addition, the course Antropologija spola (Anthropology of Gender) was introduced at the Department of Anthropology in 1993/1994. ${ }^{18}$

At master's and doctoral level, a new interdisciplinary programme entitled Women Studies and Feminist Theory commenced in 1997/1998. It was coordinated by three departments (Philosophy - Eva D. Bahovec; German Language Department - Neva Šlibar, and Sociology - Milica Antić Gaber) and had four distinct modules: Feminist Theory and Philosophy, Women's Studies in the Field of Literature and Literary Theory; Feminist Theory and Cultural Studies, and Feminism and Political Theory, each with several specific courses in their fields. Students graduating from this programme could also continue their studies at PhD level.

In this decade, the two pioneering faculties had been joined by a third, the Faculty of Social Work, ${ }^{19}$ where the first course on gender issues ${ }^{20}$ started to be given in 1993. To the best of our knowledge, it remained the only course until the new Bologna programmes were introduced.

As can be seen, the field that remained the leading force in developing WGS was sociology, but anthropology, philosophy and social work joined it in the common goal of widening the scope of the issues that had to be taught in their fields. The lecturers were still predominantly female (with only one male among them). The same can be said about the students who chose to take these courses: there were very few male students, if any.

The course titles that were introduced in this decade openly concentrated on the gender perspective and no longer masked the content with more

16 These were: Žensko pisanje (Women's Writings), S. Slapšak; Zgodovina in teorija spolov (History and Theory of Gender), I. Saksida, Z. Skušek, N. Pagon; followed in the subsequent years by Ženske- zasebno, javno, politično (Women - Private, Public, Political), later renamed as Uvodv ženske študije (Introduction to Women's Studies), M. Antić Gaber and Medkulturni vidiki koncepta spola (Intercultural Perspectives of the Concept of Gender), J. Rošker; Balkanske ženske (Balkan Women), S. Slapšak; Ženske študije in feministična teorija (Women's Studies and Feminist Theory), D. Bahovec, E. Šlibar, M. Antić Gaber, also given at the Department of Philosophy and the Department of German Language; Zgodovina žensk (History of Women), M. Verginella.

17 This course was transformed from the optional course Introduction to Women's Studies and renamed as Sociology of Gender (lectured by M. Antić Gaber), which could be offered to all of the students at the department.

18 Prof. B. Jezernik started to teach it as a mandatory course.

19 The data about the WGS courses at this faculty were provided by D. Zaviršek and V. Leskošek, to whom the author is very grateful.

20 The course entitled Ženske in moški v socialnem delu (Women and Men in Social Work) was lectured by D. Zaviršek. 
"acceptable", "neutral" or "scientific" terms as they had a decade earlier. The feminist theoretical orientation and standpoint of the new courses offered to the students in this decade was disclosed and displayed in the names of the programmes themselves, and the critical focus was oriented towards sociology as a discipline, not only to the social circumstances as such. Two master's programmes in particular widened the scope of the issues under scrutiny to sexist politics, attitudes towards women's bodies, the media, emotions and everyday life. At the Faculty of Social Sciences, several informants recollect that it was much easier for the second generation of lecturers teaching these courses in this decade, as their "founding mothers" had done the important work to make a room for them and save them from the conflicts and clashes in the academic field.

It seems that the 1990 s were prosperous years of public and academic openness to innovations, including WGS. This could be attributed to several factors: Slovenia was, at that time, a newly established independent state that had commenced broad structural changes in society (universities included); openness towards Europe and the Western world increased; liberalisation spread to many spheres of society; academic freedom was taken seriously; women's demands (led by women's and feminist NGOs) for equality in various arenas of life were more and more vocal; and female feminist academics, although small in number, became increasingly persistent in their demands for gender-sensitive knowledge production in academia.

However, in characterising the content of the development we could conclude that, in this decade, women's studies were located somewhere between the establishment and the integration phase.

\section{Between the integration and professionalisation of WGS (the times of the Bologna process)}

On closer examination of the zeitgeist at the beginning of new millennium, it is increasingly obvious that the forces of re-traditionalism became stronger and were more publicly visible. Furthermore, there was no visible improvement of the position of women in some important areas. Several examples clearly illustrate this: the share of women in politics (in key bodies) was much below the critical mass; the new NGOs established during these years were preoccupied with issues that had been marginalised by the state and its institutions (mostly social issues, violence against women, sexual harassment in the workplace, etc.); and there were some institutional changes from which we could conclude that the emphasis on women was no longer politically convenient (two examples are particularly telling: the Parliamentary Commission for 
Women's Politics and the Governmental Office for Women's Politics changed their names to more "neutral expressions": the Commission for Equal Opportunities (1997) and later to the Commission for Petitions, Human Rights and Equal Opportunities (2004) and the Governmental Office for Equal Opportunities (2001)). It seems that all of these issues - as well as many other issues, such as gender inequalities at work, the gender pay gap, the unequal distribution of tasks at home and in private life - were circulating among the publicly active women at that time. These issues were also reflected in the academic production of papers and books, and in the scope of the content of the courses given at some of the faculties offering WGS courses.

At the Faculty of Social Sciences at the beginning of the new millennium, several new courses were introduced in various programmes in sociology, political science, journalism and cultural studies. New optional courses were added to the (previous) list from which the students could choose at undergraduate level ${ }^{21}$ and several new optional seminars were added at master's level, ${ }^{22}$ thus broadening the scope of issues with which the students were acquainted, such as: work, the economy, human development and organisations, on the one hand, as well as identity politics, media, consumerism and politics, on the other (Jogan, 2011).

However, the new Bologna master's programmes introduced at the same faculty in 2010 did not have the words "women" in their titles. One module at the Sociology Department was entitled Študije spola in seksualnosti (Studies of Gender and Sexuality), which included two obligatory and two optional courses. ${ }^{23}$ As one of the informant reports, however, this module was faced with a lack of available lecturers, and for several years was not offered.

At the Department of Sociology of the Faculty of Arts, two new optional courses were introduced in the first half of this decade. ${ }^{24}$ This reflects changes

21 These were: Spolna dimenzija človekovega razvoja (The Gender Dimension of Human Development), Rener, 2004/05); Uvod v gejvske in lezbične študije (Introduction to Gay and Lesbian Studies), T. Rener, Mencin-Čeplak, R. Kuhar; Ženski žanri in politike spolov (Women Genres and Gender Politics), B. Luthar, M. Pušnik; Politika, spol in emocije (Politics, Gender and Emotions), Z. Šadl; Ženske in politika (Women and Politics), Alenka Krašovec; Politologija seksuacije (Politology of Sexuation), M. Balažic. There were also several research seminars on women's lives, one of which was entitled Ne-evropske ženske (Non-European Women), T. Rener.

22 Religija in seksizem (Religion and Sexism), M. Jogan; Spol, delo in organizacije (Gender, Work and Organisations), A. Kanjuo-Mrčela; Potrošniška kultura in spol (Consumer Culture and Gender), B. Luthar; Ženske, delo in ekonomija v ZDA (Women, Work and the Economy in the USA), A. Kanjuo Mrčela.

23 There were two: Sociologija spolnosti (Sociology of Sexuality) and Feministična teorija in študiji spola (Feminist Theory and Gender Studies), A. Švab; and two optional courses Družbena organizacija, zasebnost in spol (Social Organisation, Privacy and Gender), T.Rener; Feminizem in kulturne politike emocij (Feminism and Cultural Politics of Emotions), Z. Šadl.

24 Gejevske in lezbične študije (Gay and Lesbian Studies) was introduced in 2003, as the first course addressing this issue at the University of Ljubljana (M. Antić Gaber, Roman Kuhar). One year later, Gender and Discourse (K. Vidmar Horvat, K. Mihurko Poniž and M. Antić Gaber) was added. 
in Slovenian society, in which dealing with identity policies and media as well as other discourses became important not only scientific but also political issues in the state, which had recently become a new member of the European Union. After the Bologna programmes were introduced, several new master's courses were launched in the Sociology Department, with a special module being offered entitled Sociologija spola (Sociology of Gender). ${ }^{25}$ The wide variety of courses offered extended from body politics, queer and masculinity studies, everyday life, history, film, visual culture, to nationalism, globalisation and psychoanalysis. At this faculty, several new departments joined in the effort to introduce gender into their curricula (in languages and history), with new optional courses at the master's level. ${ }^{26}$ On the other hand, there were departments in which one would expect gender courses - as they could be beneficial in the attempt to understand gender relations and gender differences in their fields that still failed to offer even a single course with the words "women" or "gender" in its title, such as the Pedagogy and Psychology Departments.

At the Faculty of Social Work, one obligatory course was given at the undergraduate level and there were several optional courses at the master's level. ${ }^{27}$

It seems that the Bologna process itself brought new opportunities for the introduction of changes in this respect, as, among other innovations, a comparative approach with similar programmes in Europe was expected. At the

25 Sociologija spola in spolnosti (Sociology of Gender and Sexuality), M. Antić Gaber, R. Kuhar; as an obligatory course and several optional courses: Spol in telo (Gender and Body), Spol in politika v primerjalni perspektivi (Gender and Politics in Comparative Perspective), Spol in identitetne politike (Gender and Identity Politics), M. Mencin Čeplak; Spol in religija (Gender and Religion), A. Zalta; Spol in globalizacija (Gender and Globalisation), K. Vidmar Horvat and M. Antić Gaber; Kvir perspektove spola, spolnosti in identitete (Queer Perspective of Gender, Sexuality and Identity); R. Kuhar; Kritične študije moških in moškosti (Critical Studies of Men and Masculinities), R. Kuhar; Zgodovina vsakdanjega življenje žensk (History of the Every Day Life of Women), M. Verginella; Nacionalizem, rasizem in politike spola (Nationalism, Racism and Gender Politics), V. Jalušić; Psihoanaliza in tudiji spola (Psychoanalysis and Gender Studies), R. Salecl; Feministična literarna teorija (Feminist Literary Theory), A. Vogrinčič Čepič; Vizualna kultura in spol (Visual Culture and Gender), K. Vidmar Hrvat; Feministična teorija filma in televizije (Feminist Film and Television Theory), K. Vidmar Horvat.

26 At the Slovene Language and Literature Department, an optional course Spol in slovenska literature (Gender and Slovenian Literature), A. Zupan Sosič; at the German Language Department Literatura in spolna razlika (Literature and Gender Difference), I. Samide and Ženski diskurzi na prelomu iz 19. v 20. stoletje (Women's Discourses at the Turn of the $20^{\text {th }}$ Century), I. Samide; in the American Studies Programme, the course Anglo-ameriške feministične literarne študije (AngloAmerican Feminist Literary Studies), L. Burcar as a literary optional seminar; at the History Department, the optional course Zgodovina žensk (History of Women), I. Selišnik.

27 The obligatory course was Spol in nasilje (Gender and Violence), V. Leskošek; and the optional courses were: Gejevske in lezbične študije za socialno delo (Gay and Lesbian Studies for Social Work), M. Urek and A. Zorn; Nasilje nad ženskami in otroci v javni sferi (Violence against Women and Children in the Public Sphere), D. Zaviršek; and Zdravje in družbene neenakosti s perspective spola, etnije in hendikepa (Health and Social Inequalities from the Perspective of Gender, Ethnicity and Handicap), D. Zaviršek. 
Faculty of Education, ${ }^{28}$ there were previously no specifically gender and women's issues courses; only after Bologna programmes had been introduced were several optional courses given at the undergraduate level and higher levels. ${ }^{29}$

Prior to the introduction of the new Bologna doctoral programme at the PhD level at the Faculty of Social Work, students could choose between two courses on gender..$^{30}$ According to the latest information (2015/16), after the introduction of the Bologna programme, two new courses are now offered at this level. ${ }^{31}$

It seems that the most important developments were made at the doctoral level, with a new programme titled Humanistic and Social Sciences being initiated by two faculties (the Faculty of Arts and the Faculty of Social Sciences) in 2009/2010. A special interdisciplinary programme entitled Gender Studies was coordinated by both faculties but also included professors from other faculties of the University of Ljubljana and from abroad. The individual student's curriculum at the Faculy of Arts depends on the scientific field to which gender is connected; however, the basic courses are Theory and Epistemology of Gender, and Methodology of Gender Research. There are several professors for each of the courses, with selection again depending on the study field. In this way, the programme seeks to adjust to the specific needs of the doctoral students.

The development of WGS at the analysed faculties seems to depend on the topics that the lecturers themselves research, and on the main curriculum to which the topics are connected: sociology, cultural studies, anthropology, social work, pedagogy or languages and literature. Thus lecturers integrate important topics connected to gender into the main curricula and widen the student's knowledge from the gender perspective, as well. Only at two faculties (the Faculty of Social Science and the Faculty of Arts) are special modules offered at the master's level and a special programme conducted at the doctoral level. We can conclude that this outcome is the result of wider consideration of the importance of the professionalisation of WGS.

28 The data about WGS courses at this faculty was gathered by Veronika Tašner and kindly shared with the author of this paper. I am also grateful to V.Tašner for her comments and suggestions in the earlier phases of writing this paper.

29 These were: Spolno specifična socializacija (Gender Specific Socialisation), D. Zorc Maver, and Edukacija in spol (Education and Gender), S. Gaber, at the undergraduate level; Spol in edukacija (Gender and Education), M. Antić Gaber and L. Marjanovič Umek, at the master's level; and Študije spola in edukacije (Studies in Gender and Education), M. Antić Gaber, Š. Razpotnik at the doctoral level.

30 These were: Socialne politike in spol (Social Politics and Gender), V. Leskošek, and Ženske in mentalno zdravje (Women and Mental Health), D. Zaviršek.

31 Gender and the Social State (V. Leskošek) and Studies of Handicap from the Gender Perspective: The Historical and Comparative Perspective (D. Zaviršek). 


\section{The latest changes: Instead of a step forward, times of diminishing}

Informants report about the renovation of the "Bologna programmes" over the last two years, which is still not complete. As this has been influenced by the financial crisis and the consequent reduction in funding provided by the state, the rationalisation expected from the faculties related to the employment of lecturers and the subsequent reduction of programmes and courses has also had an impact on the curricula in WGS.

At the Faculty of Social Science and the Faculty of Arts, there are no more WGS modules at the master's level, only a wide list of optional courses from which students can choose, among others many courses on gender. The rationalisation behind this development is geared towards the topic of gender now being included in many other courses, resulting in less need to have special modules or so many special courses only on gender. An informant from the Faculty of Social Science also pointed out that there were tensions between two different approaches in sociology - macro and micro - with the macro approach seeming to be more powerful at a time when gender, which (according to the sociological mainstream) belongs to the micro perspective, also has a lower status and is less centrally positioned. On the other hand, a few new courses have been introduced that are closely connected to WGS - Lesbian and Gay Studies, Queer Studies, Sociology of Sexuality - which leads us to believe that there are not only backwards steps in these developments.

\section{Conclusions and limitations}

From the remarks of one informant, it is also possible to conclude that there is a lack of coordination, cooperation and support between lecturers in WGS themselves, and of support from other colleagues at the departments in which these studies are part of the curriculum. Almost all of the informants (the author of the present paper included) express their anxiety that they can expect further marginalisation of the field within academia, as well as in the wider public, as it is obvious that, in these neoliberal times when only hard science is valued, and in times of economic crisis when ordinary people think that we do not need soft knowledge such as that of the humanities, which cannot produce measurable results in terms of public spending, WGS can only expect a backlash in many directions.

Facing a backlash in women's rights in many fields of social life, lacking the support of strong political agents, strong anti-feminist sentiment, public misunderstanding of the feminist movements and feminist theory, wide 
media coverage of the "new femininity", an almost total absence of debate on transgender issues, "normalisation" of sexism in everyday life and in public debates, trans-European coalition of opponents to so-called "gender theory" with the leading proponent being the Catholic Church, to name only a few of the most visible trends, create the need for more carefully organised, financed and widely accessible WGS, and not for their shrinking or diminishing.

In closing, we would like to refer to the connection of WGS with women's and feminist movements, with NGOs' activities and academia, as we are firmly convinced that these studies were, are, and will be a political project; political in the most noble sense of the word. Without a wide coalition of support from all of the aforementioned agents (and with the support of so-called femocrats in parliamentary and governmental positions), this project can even be stopped or interrupted, as has emerged from our mapping, as our process of the institutionalisation of WGS is at least interrupted, if not endangered.

For effective policies in this respect, among other factors, ongoing analyses and critical questioning of achievements in this process are needed. The present paper is only a small contribution to this process. Its intention is to stimulate others in the field for further collective actions, support and critical contributions, as our mapping of WGS in the academic field in Slovenia has several limitations.

As this is one of the first attempts (if not the first) to cover this issue, the author has only gathered the information from the University of Ljubljana and not from the other three state universities (Maribor, Koper and Nova Gorica). Besides the limited time available for executing this task, the rationale behind this decision was that the University of Ljubljana is the oldest university in Slovenia and the one where these studies originate. For a more complete picture, however, this mapping would have to include all of the universities, and even other organisations where knowledge of WGS is produced and reproduced.

A further limitation is that (with one exception) we collected data for our mapping based on courses that contain in their names the words "women" or "men" ("femininity" and "masculinity") or "gender", and not based on all of the courses that include women's and gender issues in their course programmes but do not indicate this in their names. Including such programmes would broaden the scope of the research, but it would also make the research more complex. It would be additionally problematic because our aim was to map the development of WGS and not all of the possible courses that in any way deal with women or gender.

We also limited our research to the introduction (and lecturing) of these courses, modules or programmes in WGS, and not other issues connected to 
their development, such as: research, resources, financing, staff positions, habilitation processes, etc. These issues would definitely enrich the knowledge and improve the picture, but they would take more time and demand broader research in the preparation of this kind of mapping. We will therefore leave this for further endeavours.

\section{References}

Bowles, G., \& Duelli Klein, R. (Eds.) (1983). Theories of Women's Studies. London: Routledge and Kegan Paul.

Braidotti, R. (2003). Key Terms and Issues in the Making of European Women's Studies. In R. Braidotti \& E. Vonk, (Eds.), The Making of European Women's Studies. A Work in Progress Report on Curriculum Development and Related Issues in Gender Education and Research, Volume I (pp. 23-36). Utrecht: ATHENA, Advanced Thematic Network in Women's Studies in Europe, Utrecht University, the Netherlands.

Ginsberg, A. E. (2008). The Evolution of American Women's Studies: Reflections on Triumphs, Controversies and Change. Palgrave, McMillan, US.

Davis, K., Evans, M., \& Lorber J. (2006). Handbook of Gender and Women's Studies. SAGE. Dahlerup, D. (2015). The development of Women's Studies/ Gender Studies in the social sciences in the Scandinavian countries. Retrieved from http://koensforskning.soc.ku.dk/dokumenter/women_in_ public_life/.

Griffin, G. (2005). Doing Women's studies: Employment Opportunities, Personal Impacts and Social Consequences. London \& New York: Zed Books.

Griffin, G. (2006). Women's/Gender Studies, Professionalization and the Bologna Process-CrossEuropean Reflections. NORA - Nordic Journal of Feminist and Gender Research, 14(2), 87-102, DOI: $10.1080 / 08038740600999866$.

Humm, M. (1989). The Dictionary of Feminist Theory. London: Harvester Wheatsheaf. Jalušič, V. (Ed.) (2002). Kako smo hodile v feministično gimnazijo [How We Attended a Feminist Grammar School]. Ljubljana: ${ }^{\star} \mathrm{cf}$.

Jaschik, S. (2009). The Evolution of American Women's Studies, an interview with A. E. Ginsberg. Retrieved from https://www.insidehighered.com/news/2009/03/27/women.

Jogan, M. (2006). My life as a (female) sociologist. In M. F. Keen \& J. L. Mucha, Autobiographies of Transformation. Lives in Central and Eastern Europe (pp. 21-46). London and New York: Routledge. Jogan, M. (2011). 1961-2011: Spol, spola, spolna neenakost in znanost na FDV, Spremno besedilo $k$ razstavi ob 50-letnici FDV [1961-2011: Gender, Two Genders, Gender Inequality and Science at the Faculty of Social Sciences. Accompanying Text for an Exhibition on the $50^{\text {th }}$ Anniversary of the Faculty of Social Sciences]. Manuscript.

Mlinarevic, G., Kosović, L., Slavova, K., Hašková, H., Põldsaar Marling, R., Pavlidou, T. S., et. al. ... Daskalova, K. (2010). The Birth of a Field. Women's and Gender Studies in Central, Eastern and 
Southeastern Europe, Aspasia. Retrieved from http://dx.doi.org/10.3167/asp.2011.050109.

Silius, H. (2002). Summary Report: Background Data - Women's Employment, Equal Opportunities and Women's Studies in Nine European Countries. Retrieved from www.hull.ac.uk/ewsi.

The Impact of Women's Studies Training on Women's Employment in Europe (2007). Retrieved from http://cordis.europa.eu/docs/publications/1001/100124171-6_en.pdf.

Tuning Educational Structures in Europe, Reference Points for the Design and Delivery of Degree Programs in Gender Studies (2010). Retrieved from http://tuningacademy.org/wp-content/ uploads/2014/o2/RefGender-Studies_EU_EN.pdf.

\section{Biographical note}

Milica Antić Gaber, PhD, Full Professor at Department of Sociology, Faculty of Arts, University of Ljubljana where she among others teaches Sociology of gender and coordinates doctoral program Gender Studies. She chairs a section Gender and Society in Slovene Sociological Association. She was also a member of the Expert Forum of European Institute for Gender Equality and is a member of the Expert Council for Gender Equality in Slovenia. She contributed numerous chapters and articles in journals and edited books on gender equality, the latest titled Gender Structuring of Contemporary Slovenia. 